\title{
Analysis on the Legal Regulation of Green Finance Development from the Perspective of Ecological Civilization
}

\author{
Hongii Wang * \\ School of Finance \\ Guizhou University of Finance and Economics \\ Guiyang, China \\ 1507714060@qq.com
}

\author{
Jianhua Zhu \\ School of Finance \\ Guizhou University of Finance and Economics \\ Guiyang, China \\ 948841731@qq.com
}

\begin{abstract}
The 19th National Congress of the Communist Party of China proposed to promote the reform of the ecological civilization system, accelerate the establishment of a policy guidance and legal system for green production and consumption, and establish and improve the economic system for the sustainable development of the green low-carbon cycle. At the same time, the market oriented green technology innovation system should be constructed to strengthen the green low-carbon industries such as energy saving and environmental protection, new energy sources and new technologies, so as to create new economic growth points and realize the conversion of new and old kinetic energy. From the perspective of ecological civilization and the theoretical research foundation of green financial legal system at home and abroad, this paper forms a series of legal framework ideas in view of the present situation of green financial regulation construction in China, and then puts forward some policy suggestions for restructuring regulation.
\end{abstract}

Keywords-ecological civilization; green finance; low-carbon economy; laws and regulations

\section{INTRODUCTION}

With the continuous development and promotion of green financial project activities, related industries, especially energy conservation and environmental protection, clean energy, green and low-carbon industry, etc., have become the market orientation of green circular economy development, and the investment in green environmental protection industry has become an irresistible trend. [1] In 2007, the General Administration of Environmental Protection of China, the People's Bank of China, and the China Banking Regulatory Commission jointly formulated and promulgated the "Notice on Prevention and Control of loan risks in highly polluted Industries", which has opened up the practice of green finance. The green financial system based on "green credit", "green insurance" and "green securities" was proposed and constructed in this notice to offer a rare opportunity transform China's economic development model for sustainable development. On the eve of the G20 summit in Hangzhou in 2016, China's seven ministries and commissions jointly issued the "Guiding Opinions on Building a Green Financial System" to accurately define green finance, and included green finance in key discussion topics at the summit. The key significance of green

This paper is a phased achievement of the National Social Science Foundation Project (12BMZ076) and the Ministry of Commerce's key research topic (2015SWBZD19). development in the world economic and social development is emphasized deeply, and the financial industry is more powerful to promote the world green development at the same time.

\section{THE PRACTICAL SIGNIFICANCE OF LEGAL REGULATION ON GREEN FINANCE DEVELOPMENT}

Green finance refers to using financial as a carrier to readjust the financial industry's business philosophy, management policies and business processes from the perspective of environmental protection, and to guide corporate funds to sustainable development, clean energy, energy conservation and environmental protection, green transportation, green buildings and other fields through financial means. For the purpose of promoting green energy resources and "climate finance" to reduce greenhouse gas emissions, promote enterprises to reduce energy consumption, achieve technological innovation, adjust the industrial structure, and ultimately promote a win-win situation for environmental protection and economic benefits. Taking energy conservation and environmental protection as the credit orientation, we will build a new model of green finance development. At the same time, we should support green industry with more safe and efficient financial services, further promote the development of ecological civilization, and finally build a sound legal system based on the effective development of green finance. The system ensures the healthy development of green finance through legal regulation at the national level.

\section{A. Impose Mandatory Means on the Financial Industry to Assume Social Responsibility}

Many enterprises blindly pursue industry development, while local governments unilaterally attach importance to political achievements, ignoring high energy consumption, high pollution and high emissions, resulting in the increasingly intensified contradiction between environmental problems and economic development. However, the commercial loans of the financial industry play a key role in the rapid development and expansion of these industries. On the one hand, the effective use of resources provides favorable conditions for enterprises to maximize their benefits. On the other hand, the financial industry should take the initiative to assume certain social responsibilities and will make full use of prudent financial professional service opportunities and consciously adopt the 
principle of harmonious development of environmental issues, social risks and economic development. But it is far from enough to rely solely on the financial industry to consciously assume social responsibility. It must be accompanied by certain coercive means. For example, by attributing the standard of green credit project lending to the commercial bank law, upgrading the legislative level, strictly controlling of such loans through effective measures, causing the 'two high" enterprises to pay attention to the environmental protection issues of enterprises, controlling violations of over-limit enterprises from the source of financing at the time of approval. Adhere to the quality first, benefit first, further promote enterprise energy saving and emission reduction, reduce energy consumption; continue to increase social welfare through technological innovation, so as to promote sustainable development of society and corporate profits.

\section{B. Green Financial Legislation is Conducive to the Promotion of Circular Economy}

In the long run, China will still face sharp contradictions and tremendous pressures between economic development and resources and the environment. This is undoubtedly a prominent problem in China's economic and social development. At present, China's economy has changed from high speed growth to high quality growth. It is in the crucial period of changing the mode of economic development, optimizing the economic structure, and transforming the driving force of economic growth. The construction of modern economic system is an important strategic goal to promote the economic development of our country. Adjusting China's economic growth mode can adopt a circular economy and a low-carbon economy, thus promoting green finance to play a key role in sustainable economic development. However, the promotion of circular economy needs strong means as support and law as the guarantee, so establishing and perfecting green financial legislation can combine the green development of ecological civilization with the economy and maximize the synergistic effect of the two.

\section{Ecological Civilization Construction Expands Green Finance Business}

As the country attaches importance to environmental protection, environmental issues make financial industry opportunities and challenges coexist. With the background of ecological civilization, under the advocacy of low-carbon economy and circular economy, the demand for environmentally friendly products has increased greatly, and the rapid development of environmental protection industry has been promoted, which has provided a new source for the expansion of the financial industry. The environmental protection industry has become the focus of international trade competition, governments and financial institutions have continuously strengthened the construction of ecological civilization, and developed a series of financial products, and formulated relevant financial policies, including green credit, green insurance and green securities. Green credit is mainly used to guide funds to energy conservation and environmental protection projects through credit approval in credit approval requirements, and to limit the credit line of high-pollution and high-emission enterprises; green insurance refers to the requirement that enterprises with environmental safety hazards purchase liability insurance. Once a pollution incident occurs, the enterprise can assume its corresponding responsibility; Green securities refer to the management of high-pollution and high-emission enterprises from the source to limit the scale of development of such enterprises. Therefore, green finance can help financial institutions to develop a strategy of adaptive development based on a sustainable circular economy, so that they can benefit from the ecological environment, expand green financial services, and enrich the types of green financial products.

\section{THE STATUS QUO OF THE CONSTRUCTION OF GREEN FINANCIAL LEGAL SYSTEM}

\section{A. The Status Quo of the Construction of China's Green Financial Laws and Regulations}

Compared with the developed countries, the development of green finance in China started late.[2]In 2007, the State Environmental Protection Administration, the people's Bank of China and the Banking Regulatory Commission jointly issued "the notice on preventing and controlling loan risks in highly polluting industries”, which is seen as the beginning of a green credit policy that requires banks to increase environmental risk assessments in the loan approval process. At the same time, we should improve the regulatory system and policies related to the content of green credit, and add some restraint and incentive mechanisms in the process of implementation. In 2008, Industrial Bank became the first "Equator Bank" in China, and the first bank in China to launch the "Energy Conservation and Emission Reduction Project Loan" project. It successfully established the image of "Green Credit" pioneers and advocates in China, and constantly exploring the depths of green finance. In 2009, the first sustainable financial institution, was established--the Sustainable Finance Center. In 2010, the company launched the first low-carbon ICT card in the country, and expanded green finance from the enterprise project field to the personal consumption field. In 2011, China issued the first innovative green financial products such as carbon assets pledge loan. In 2012, the CBRC issued the "Green Credit guidelines" to establish the operational regulation of green credit.[3]In 2015, the NDRC issued the "Green Bond issuance guidelines," proposing that corporate bond financing play a supportive role in promoting green development, promoting energy conservation and emission reduction, solving environmental problems, and tackling climate change. The applicable scope of green bonds and the efficiency of audit, access conditions, guarantee credit enhancement and other preferential policies.

Up to now, China's financial industry has formed a "trinity" development pattern, which is mainly green credit, green insurance and green securities, with normative documents and advocacy documents as the action guide. However, this mechanism is not perfect enough. Therefore, China's green finance should design heterogeneous financing schemes based on different product characteristics in various green product developments, expand the coverage rate of financing products, and increase the participation of financial institutions. These require us to continuously improve and perfect the green financial system, combine the corresponding institutional and even mandatory measures to protect, and develop targeted and 
green financial-related legislation to build a complete and effective mechanism. In short, in order to further promote the development of green finance, it is urgent to formulate corresponding laws and regulations.

\section{B. Problems in the Green Financial Legal System}

1) Low legislative level. The main reason why the legislation of green finance in our country is not perfect is that compared with the western developed countries, the green finance starts later and does not form a mature basic theory. Although the national leaders have paid more and more attention to environmental protection issues in these years, and the public's awareness of environmental protection has improved, the existing legal documents belong to the normative documents formulated by the State Council and relevant ministries, it is often only a policy-oriented and propaganda role, but is not the national supreme authority organ to the green finance legislation, which is protected by law and has certain compulsory and authoritative nature. On the other hand, these normative documents are not wideranging, often only for one aspect of green finance, and it is difficult to effectively link information by point and face. It is also necessary to form a complete system to provide systematic legal support for China's green financial legislation. For example, the implementation of China's environmental protection law, because the legal status of the Environmental Protection Law is not high, lack of authority, and the grassroots law enforcement capacity is weak, many high-tech enterprises ignore it, which makes it difficult to implement China's environmental protection law.

2) Incomplete content. Our country green finance mainly involves the green credit, the green insurance and the green security three aspects. However, at present, the green finance legislation of our country is limited to the green credit of commercial banks, and there is still a lack of heterogeneous legislative provisions in green insurance and green bonds. Most of the existing green finance laws belong to the field of pollution control, and few legal contents are formulated for environmental protection, energy saving, new energy technology and low-carbon finance. There is a lack of reward and punishment system in policy formulation. Many articles only emphasize that the financial industry must bear social responsibility and issue loans in strict accordance with the approval procedures. However, the institutions responsible for violating environmental protection principles have not clearly defined the corresponding accountability system and punishment system. In the aspect of tax policy, the state supports the green finance project by reducing the tax revenue, but does not clearly explain which items in the green finance project can obtain the preferential tax policy.

3) Lack of operability. On the one hand, it is mentioned that China's existing green finance legislation is formulated by the ministries and commissions with policy guidance as the normative document. Due to the lack of compulsory and authoritative nature, it is difficult to implement and implement in the practice process, so it lacks operationality. On the other hand, the lack of a clear reward and punishment mechanism will greatly weaken the implementation of relevant policies, which is also an important factor leading to the lack of operability. Finally, China's green finance law does not clarify the legal rights and responsibilities that social entities need to bear in them, so the main force of green financial participation cannot play a guiding role.

\section{The Conception of Perfecting the LegAL Regulation of Green Finance Development}

A reasonable legal framework system can maximize its own utility. Therefore, in the aspect of green financial legislation, a scientific method is also needed to rationally construct the legal system, highly integrated departmental rules and regulations, administrative laws and regulations, and local guidance with the adjacent environmental protection legal system to form a static structural system. Only from the content structure of the legal regulation of green finance, its meaning revolves around the word "green", that is, the theme of the development of green finance under the view of ecological civilization, and its domain mainly involves the credit loan of the banking industry. The security of the company and the insurance industry in advance.

Secondly, we should vigorously develop the legal system of green securities. In terms of the legal system of green securities, one is to join the requirements of environmental protection into the financing activities through securities supervision and establish a corresponding evaluation system. The second is to reinforce the information disclosure system and environmental reporting system of listed companies, strengthen the importance of environmental information disclosure, guide enterprises to take environmental issues into account when implementing decisions, and strengthen the importance of enterprises to their own environmental risk management. Third, when promoting green finance legislation, the securities industry should play the role of a fund provider, and provide the greatest support for enterprises to carry out green projects in the face of funding needs. For example, we can add the contents of funds, which is related to environmental factors into "the Securities Investment Fund Act".

Finally, we should speed up the establishment of a green insurance legal system. At present, China has a policy guidance related to green insurance, namely, "Guiding Opinions on Environmental Pollution Liability Insurance". But the legal provisions on environmental pollution liability insurance are still relatively lacking, so a green insurance legal system should be established. In addition, in order to ensure the reasonable division of liability in the event of an accident, different types of heterogeneous insurance should be designed scientifically for different industries and the scope of each subject should be defined legally.

\section{Policy Suggestions on Reconstructing Legal REgulations fOR GREen FinANCE DEVElOPMENT}

\section{A. Give full play to the Synergy of "soft and hard methods"}

"Soft and hard Law" refers to the "opinions" or "guiding opinions" formulated by the State Council and relevant ministries and commissions, which have the characteristics of 
policy and guidance, as well as the hard laws formulated by the highest legal departments of our country with mandatory characteristics. In order to establish perfect green finance laws and regulations, we must give full play to the synergy of "soft and hard laws". First, the soft law is the first method of hard law. The soft law is a self-disciplined norm and does not require national government intervention. Its advantage is to fully mobilize social enthusiasm and increase the participation of the people. Therefore, the soft law is temporarily suspended before the hard law legislation, and some effective soft laws are further improved through practice to provide reference for the establishment of the hard law. Secondly, the hard law is supplemented by soft law. Because the establishment of the hard law is more normative, it leaves a lot of blanks, and the soft law is more flexible. It can be adjusted according to the actual situation at that time to make up for the shortcomings of the hard law. It can be seen that in the construction of legal regulation of institutional green finance, it is necessary to form a mode of both soft and hard, and promote the synergy between soft and soft law of green finance.

\section{B. Establishing and Perfecting the Reward and Punishment System of Green Finance Development}

In China's existing green financial reward and punishment system, mainly based on restrictive norms, there are fewer corresponding incentive measures. For industries that are not conducive to environmental protection, we should not only adopt restrictive norms in the process of financing, but also establish a punishment mechanism for such enterprises. Incentives should be taken for industries that are conducive to ecological civilization and sustainable development. To develop green finance, it is necessary to use incentive measures to promote the participation of all subjects, and to use tax policy, credit quota, reduction of responsibility and obligation to influence the decision-making behavior of enterprises. For example, enterprises that meet the requirements of green environmental protection are provided with tax reduction and exemption fees, lower loan interest rates, and financial subsidies, and further provide financing facilities for such enterprises. Therefore, the combination of restrictive norms and encouraging norms can effectively promote the rapid development of green finance.

\section{Constructing the System of Green Financial Risk Prevention}

Green finance, as a financial activity, also faces a variety of risks. For example, the development of green finance needs to introduce new technologies, but technological innovation requires a process. As a result, when the technology is at an immature stage, it is impossible to estimate whether the final income can be greater than the previous input cost, so there is a lot of uncertainty that creates market risk. The most important thing to ignore is the moral hazard. Some enterprises may obtain funds for approval for non-compliance projects, and they will use the fraudulent means of fiction and whitewashing to package the project into a green environmental protection project and cause moral hazard. Therefore, it is necessary to construct a financial risk prevention system based on the consideration of security. First of all, each subject is required to perform the duties of information disclosure. The openness and transparency of the information is conducive to the public to understand the green project of the enterprise and provide convenience for the relevant regulatory authorities. Finally, the enterprise that exists fraud in the green project is punished strictly, and the behavior of violating the principle is restrained.

\section{CONCLUSION}

In summary, according to the current situation of China's green finance development, combined with the problems existing in the construction of legal regulation in China's green finance, it can be concluded that it is difficult to form a systematic legal system based solely on the opinions and guidance documents issued by various ministries. Faced with these thorny issues, providing institutional support and legal guarantees for green financial development has added challenges, and it has also provided a broader space for development of China's green financial legislation. We should implement the existing policy measures, shoulder the important task of providing guarantees for the development of green finance under the vision of ecological civilization, and adopt more scientific and perfect laws and regulations to publicize and guide the implementation of green finance in the whole society.

\section{REFERENCES}

[1] Yang Feng. On the legal Regulation of Green Finance, People's Forum, no.2016 (14), pp 125-127.(In Chinese)

[2] Yuan Kang. Green Financial Development and its legal system guarantee, Stock Market Bulletin, no.2017(01), pp 4-11. (In Chinese)

[3] Fan Shaohong. The legal system of Green Finance: the ought Choice and realistic Construction from the Perspective of Sustainable Development, Journal of Wuhan University, no2013(02), pp 66. (In Chinese)

[4] Li Ruoyu. China's green finance development status and policy recommendations, macroeconomic management, no.2016 (01), pp 58-60. (In Chinese)

[5] An Guojun, Cao Chao. International leg islation and reference of Green Finance, China Financial Department, no, 2017 (18), pp 74-76. (In Chinese)

[6] Liu Naigui, Wu Tong. Study on the legal safeguard Mechanism of Green Finance, Financial Science, no.2017 (10), pp 41-51.(In Chinese) 